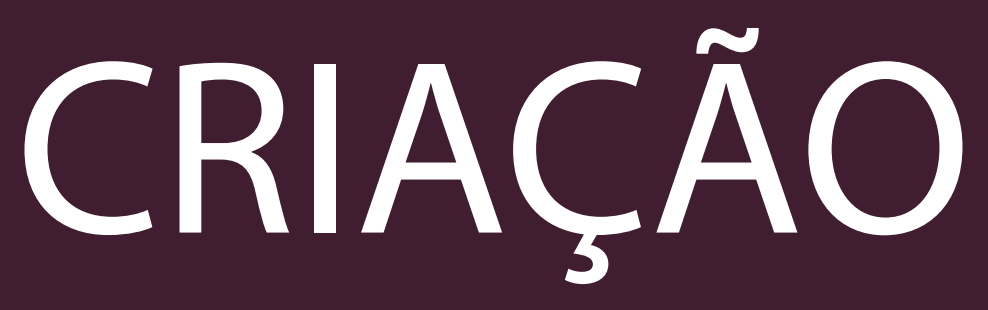





\section{A CIDADE}

- RENATO AMADO BARRETO

\section{A PEDRA}

A planície do Rio de Janeiro é limitada, no litoral sul, por praias de mar aberto. Na região central ergue-se o Maciço da Tijuca, granito-gnáissico, impondo uma barreira geográfica entre as regiões sul e norte que estimula precipitações de um lado e doutro. Grande parte desta formação rochosa é tomada pela Floresta da Tijuca, terceira maior floresta urbana do planeta, que tem flora e fauna típicas de Mata Atlântica, bioma que se espraia por grande parte do litoral brasileiro, esticando-se de um Rio Grande ao outro.

Algumas das plantas mais comuns na Floresta são o angico, o cedro, o ipê, a quaresmeira, o palmito, a mangueira, o bambu e o jambeiro, sendo as três últimas não nativas.

A acidentada geografia da cidade ainda conta com mais dois maciços: da Pedra Branca, sobre o qual deita raízes a segunda maior floresta tropical do mundo; e o Gericinó. Ambos ficam na Zona Oeste do município.

Contornando-se o Maciço da Tijuca pelo leste, é possível atravessar da Zona Norte à Zona Sul. Por ser a região de passagem entre norte e sul e onde a cidade mais se desenvolveu até as primeiras décadas do século XX, é conhecida como Centro da Cidade.

O Centro é plano desde a demolição do Morro do Castelo, em 1922, com o fim de aumentar a circulação de ar, o que levaria os micróbios para outras bandas e reduziria a canícula. Nisto, certamente, não houve sucesso, uma vez que até hoje é uma das partes da cidade onde mais se passa calor, com a temperatura ultrapassando insuportáveis quarenta e dois graus nos dias mais quentes do ano. Somente no inverno o clima do Rio de Janeiro é ameno. O outono e a primavera são estações idênticas, com temperatura na linha média entre o agradável e o inadequado ao organismo humano.

O Maciço da Tijuca, a oeste, e a Baía de Guanabara, a leste, são os limites geográficos do Centro. Fronteira natural colossal, esta é a segunda maior baía brasileira, com 380 quilômetros quadrados de área. Banha vários municípios e seu formato lembra um rascunho do mapa nacional. Tem diversas ilhas, dentre as quais se destacam por sua extensão ou relevância histórica ou social: Villegagnon, Governador, Fundão, Paquetá e Fiscal.

A llha Fiscal fica próxima à Praça Quinze de Novembro, onde se encontra a 
Estação das Barcas, pequeno porto do Centro da Cidade do qual partem ferries para a cidade vizinha de Niterói e para algumas das ilhas.

A Praça Quinze de Novembro é delimitada pela própria Baía de Guanabara, pela Avenida Primeiro de Março, pelo Paço Imperial e pelo Arco do Teles. Por cima dela, ao menos por enquanto, passa o Viaduto da Perimetral.

A Perimetral é um grande viaduto que começa no Centro da Cidade, próximo ao Aeroporto Santos Dummont, e se conecta a outros elevados, como a Linha Vermelha e a Ponte Rio-Niterói. Em seu trajeto há acessos para importantes endereços, como a Praça Mauá e o entorno da Igreja da Candelária, imponente construção localizada na Av. Presidente Vargas.

A Av. Presidente Vargas é a veia aorta do Centro. Tem três pistas, cada uma delas com quatro faixas, cinco estações de metrô e circulação de ônibus para quase todas as partes da cidade. Não bastasse, ao seu lado ficam a Central do Brasil, núcleo nervoso da rede de transporte público da metrópole, e a sede da Prefeitura.

Essa avenida, assim como toda a região, tem muito concreto e pouco verde. É ladeada por grandes caixas que esfregam ombros umas nas outras e das quais, no meio e no fim do dia, escapa uma quantidade inimaginável de pessoas. Nestes horários, o frenesi de pedestres supera o de automóveis e caminhar só é possível em ziguezagues.

Não é encostada ao Maciço da Tijuca, mas ele chega até ela. Seja como produto de antigas pedreiras, seja por pequenas rochas que rolaram há séculos e foram se dividindo e se locomovendo por ação humana à razão de alguns metros por década, de modo que alguns granitos de poucas centenas de gramas são encontrados aqui e ali.

\section{O CIDADÃO}

O nativo do Rio de Janeiro é conhecido como carioca, por conta de histórico rio homônimo que nasce na Floresta da Tijuca e morre na Praia do Flamengo, na Baía de Guanabara. Ele foi fundamental para o crescimento da urbe, tendo abastecido o Centro e arredores através do Aqueduto da Carioca, que, depois de desativado, passou a ser chamado de Arcos da Lapa, hoje cartão-postal da zona mais boêmia da cidade e urinol informal.

O jeito aberto e cordial do carioca é indevidamente associado à preguiça $\mathrm{e}$ à falta de combatividade. $\mathrm{O}$ ambiente praiano, o tino musical e o falar arrastado Ihe deram traços de caricatura de baiano. Mas o carioca é, antes de tudo, um militante. Basta um incidente para que seus modos aparentemente lânguidos se transmudem. Um rápido passar d'olhos pela história demonstra: revolta da armada, revolta da vacina, revolta do vintém. Motivadas por razões tão diversas 
quanto insatisfação com o sistema político ou cobrança de vinte centavos pela passagem de bonde.

Bem educado no Colégio Pedro II, Rodrigo, morador da Usina, bairro de classe média situado na base norte do Maciço da Tijuca, cercado por concreto de um lado e floresta de outro, sempre teve um encanto especial pelas revoltas do Rio de Janeiro, por isso, enquanto conclui a faculdade de História, vai decidindo qual delas será objeto de sua dissertação de mestrado. Costuma pensar sobre isso enquanto corre. Tem o hábito de ir e voltar do estágio, próximo à Praça Quinze de Novembro, correndo, percorrendo um total de aproximadamente vinte quilômetros. Aos sábados pela manhã faz cooperno Aterro do Flamengo, onde passa sobre a foz do Rio Carioca três vezes.

Politizado, reduziu os exercícios no período eleitoral de 2012 para fazer campanha para seu candidato a prefeito. Para desconhecidos panfletava e explicava o programa de governo. Para os companheiros expunha algumas ideias e escutava muitas. Fazia, de forma branda, papel de advogado do diabo, a fim de, na verdade, ser convencido. Queria adotar alguma bandeira. Sempre teve dificuldade de se alinhar a movimentos, uma vez que, invariavelmente, encontrava pontos de desacordo não apenas em detalhes, mas em questões nevrálgicas. E, normalmente, as ideias dos grupos já estavam consolidadas demais para que ele conseguisse mudá-las. Isso o colocava, apesar de seu inconformismo latente, em uma lassidão que o incomodava. Decidiu, por fim, ignorar algumas diferenças e abraçar a causa do seu candidato escolhido, em prol de um miolo ideológico. Não havendo opção mais próxima de suas convicções, ajudaria a melhor dentre as em voga a se tornar realidade.

Sua ajuda, entretanto, de nada serviu, e seu candidato foi derrotado logo no primeiro turno.

E o IPTU subiu. E desapropriações em prol da especulação imobiliária e em nome da Copa do Mundo e das Olimpíadas, eventos que ocorrerão no Rio de Janeiro poucos anos após a data dos fatos narrados, continuaram sendo feitas. E a passagem de ônibus subiu.

A tarifa do transporte público não aumentou apenas no Rio de Janeiro, mas em várias cidades do Brasil, como São Paulo, localizada num planalto da Serra do Mar - cadeia montanhosa que se estende por grande parte do centro-sul do país -, a cerca de 450 quilômetros do Rio de Janeiro. O Movimento Passe Livre, que defende transporte público gratuito, foi às ruas reclamar de mais este aumento, uma constante nas metrópoles nacionais. A República respondeu às manifestações com bombas de gás lacrimogêneo e spray de pimenta fartamente utilizados pela Polícia Militar do Estado de São Paulo.

Havia uma insatisfação histórica com os poderes constituídos. Uma sensação de falta de representatividade, a despeito da democracia representativa. Uma falta de ingerência do povo nos assuntos da coletividade, discutidos 
somente em gabinetes. A polícia, órgão público, agrediu quem se manifestava por ter sido assaltado por mais um aumento da tarifa de ônibus. As imagens correram o país e foram o estopim para que passeatas se alastrassem.

Rodrigo rapidamente aderiu ao movimento e conheceu o lacrimogêneo, um composto gasoso à base de substâncias irritantes da pele e das mucosas, tais como brometo de benzila. É como se moléculas de pimenta se amalgamassem às da atmosfera e atacassem, juntas, o rosto da vítima, entrando pelos olhos e vias respiratórias. Depois de seguirem toda vida pelas vias aéreas desembarcam nos pulmões, que, através dos alvéolos, entregam-nas aos glóbulos vermelhos, que as transportam sem custo para o resto do corpo. Quando chegam ao coração, combinam-se às enzimas de agressividade que, subindo pelos vasos capilares, fixam-se à epiderme.

\section{O CHOQUE}

Às $16 \mathrm{~h} 30$ Rodrigo encontrou, no Largo da Carioca, amigos do partido que apoiara nas eleições do ano anterior e com o qual vinha flertando desde então. Desceram a Av. Rio Branco em direção à Candelária, onde estava marcado o início de uma grande passeata. Levavam vinagre, para neutralizar os efeitos do gás lacrimogêneo, e três cartazes: um favorável ao transporte gratuito, outro contra a violência policial e um com um risco por cima de uma seta que apontava a direita. Rodrigo ficou com o segundo. Caminharam sem formação, observados pelo bem postado Batalhão de Choque da Polícia Militar.

Em alguns minutos estavam na Candelária, compondo uma multidão em formação. Palavras de ordem eram entoadas. Rodrigo e seus amigos faziam coro com as que concordavam. Não demoraram a iniciar a marcha, pela Avenida Presidente Vargas, em direção à Cidade Nova, bairro onde fica a sede da Prefeitura.

À disposição no batalhão do Centro: são o Batalhão de Operações Especiais (BOPE), a tropa de elite. Quando viesse a ordem era "chegar pra resolver", disse o capitão.

Armadura, escudo. Rostos cobertos por máscaras e viseiras. Eram ciborgues. Máquinas não usadas quebram. Máquinas de guerra oprimem. Cão encurralado se esgueira para fugir ou ataca. $\mathrm{O}$ cão já vinha sendo atiçado pela máquina há décadas. 
Um granito de trezentos gramas voou, parando num escudo.

Bombas de efeito moral abriram uma clareira na multidão, pouco depois coberta pela massa que vinha da Candelária. Foi o primeiro assalto.

"A sede da prefeitura está ameaçada", disse o governador ao capitão da Polícia Militar ao ver a cena na televisão. $O$ recado foi transmitido aos superiores do BOPE e do Batalhão de Choque.

Num erro de estratégia, o Choque não esperou o BOPE chegar. Ansiosos, os ciborgues disparavam bombas de gás e manifestantes corriam atarantados, causando pontuais e breves dispersões. Foram três investidas deste tipo, absolutamente inúteis, até que o BOPE chegou.

Promoveriam pequenos cercos. Uma unidade vinha de um lado, outra de outro. Assustados, a maioria dos cariocas fugiria. Aos que ficassem não faltaria munição. Balas de borracha podem ser usadas sem necessidade de registro de auto de resistência.

A primeira batalha foi em frente à Prefeitura. Alguns homens recuados atiravam bombas de gás que pousavam na multidão, instaurando o desespero. À medida que os cariocas tentavam escapar do gás se aproximavam dos pelotões de vanguarda que, com seus fuzis, alvejavam-nos. As áreas onde aterrissavam as bombas ficavam rapidamente desertas, tornando-se praças inexpugnáveis. Mas alguns militantes encontravam abrigos nas redondezas e de lá atiravam granitos, favorecidos pela escuridão, já que a própria polícia determinara o apagamento das luzes, para prevenir registros audiovisuais. Acuado pelas pedras atiradas por fantasmas, o BOPE recuou. Guardaram posição e só voltaram a avançar sob a proteção dos escudos do Choque. Seguiu-se nova artilharia de bombas de gás e os militantes entocados foram obrigados a se expor em busca de novos abrigos. No caminho, balas de borracha. Algumas os atingiam de tal forma que os tiravam de combate.

Manteve-se a carga até que sobraram um professor aposentado, dois homens de meia-idade e um secundarista. Eles se renderam e foram, aos trancos, levados à delegacia mais próxima sem, contudo, perderem a altivez.

O assalto seguinte foi em frente à Central do Brasil. Uma multidão que carregava cartazes e entoava gritos de ordem foi surpreendida pelas bombas 
que caíam em locais aleatórios. Enquanto o roteiro do combate anterior se repetia Rodrigo foi atingido por um tiro nas costas. Abandonou sua cartolina e correu até fugir do cerco. Só então sentiu com toda a intensidade a dor do ferimento. Lembrou-se das vezes que inalou gás lacrimogêneo desde o início das manifestações. A evocação das memórias pôs seu corpo em movimento. Corria em direção a um policial que estava de costas, atirando contra uma multidão ou contra o nada. Ao se aproximar pulou e jogou o pé direito para frente.

O golpe surpresa derrubou Cabo Moreira.

Rodrigo não esperou ele se recompor. Virou-se de costas e, como quem disputa uma prova de cem metros com obstáculos, disparou pela Avenida Presidente Vargas em direção à Candelária, ziguezagueando para desviar dos fugitivos mais lentos. Enquanto escapava ouvia tiros, sentia balas passarem rentes à sua cabeça. Corriacorria. Se afastava do local onde atacara o inimigo, mas as balas continuavam vindo, de todas as direções. Percebia que não se tratava de uma vingança contra ele, mas de um bombardeio sobre toda a área. As forças da República retomavam o espaço ocupado pelos cariocas. Continuava correndo, em meio a explosões, gritos, tiros e fumaça. Já se perdera de seus amigos. Passava pela esquina com a Avenida Rio Branco quando uma bala atingiu seu rosto, derrubando-o. Pousou as mãos sobre a ferida, que doía muito, e levantou-se o mais rápido que pôde. Seguiu. Ao passar pela Igreja da Candelária persignou-se e, metros depois, avistou o acesso à Perimetral. Subiu.

O ruído que vinha lá debaixo era disperso e distante. À medida que se afastava, a sua respiração, os tênis chocando-se contra o solo, e o marulho da baía abafavam outros sons. Foi tomado pelo êxtase da corrida. Fazia o que mais gostava, afinal. Mais à frente estava o Aterro do Flamengo, onde passaria mais de três vezes sobre a foz do Rio Carioca.

Estava a salvo. I

RENATO AMADO BARRETO - É doutorando e professor assistente na Brown University. Publicou o romance Vale do Rio Preto, em 2008, pela editora Multifoco. 